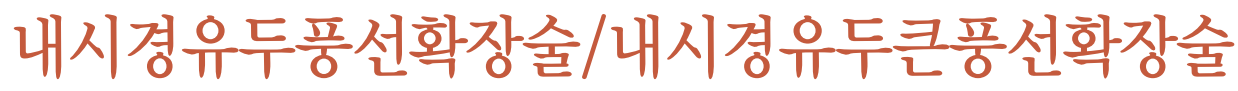

인하대학교 의과대학 내과학교실

정 석

\title{
Endoscopic Papillary Balloon Dilation/Endoscopic Papillary Large Balloon Dilation
}

\author{
Seok Jeong \\ Department of Internal Medicine, Inha University College of Medicine, Incheon, Korea
}

Endoscopic papillary balloon dilation (EPBD) and endoscopic papillary large balloon dilation (EPLBD) have been performed all around the world over several decades for the treatment of common bile duct stone. EPBD using small dilation balloon catheter can preserve sphincter of Oddi function and reduce the recurrence rate of bile duct stone compared to endoscopic sphincterotomy (EST). EPBD is a procedure with low risk of bleeding, which is appropriate for patients with coagulopathy, hepatic cirrhosis, end-stage of renal disease, and surgically altered anatomy such as Billroth II gastrectomy and periampullary diverticulum. However, it has a higher risk of postprocedure pancreatitis than EST. EPLBD using large balloon catheter $(12 \mathrm{~mm}$ or more of diameter) is proper for more than $10 \mathrm{~mm}$ of common bile duct stone. The advantages of EPLBD are reduced need for mechanical lithotripsy with decreased procedure time and radiation exposure time irrespective of the precedence of EST. EPLBD also requires fewer endoscopic retrograde cholangiopancreatography sessions and is more costeffective. The incidence of post-procedure pancreatitis is lower in EPLBD than EST. If EPBD and EPLBD are done under the guidelines, these would be safe and effective and may be alternatives to EST for common bile duct stone.

Korean J Pancreas Biliary Tract 2019;24(4):175-181

Keywords: Choledocholithiasis, Endoscopic papillary balloon dilation, Endoscopic papillary large balloon dilation, Sphincterotomy, Endoscopic

\author{
Received May 7, 2019 \\ Revised Jul. 2, 2019 \\ Accepted Jul. 9, 2019
}

Corresponding author : Seok Jeong

Department of Internal Medicine, Inha University Hospital, Inha University College of Medicine, 27 Inhang-ro, Jung-gu, Incheon 22332, Korea

Tel. +82-32-890-2548 Fax. +82-31-890-2549

E-mail; inos@inha.ac.kr

ORCID: https://orcid.org/0000-0001-6178-8338

\section{서 론}

총담관결석증의 내시경 치료에 있어, 결석을 제거하기 위하여 필수적인 사전시술로서 담도 입구인 주유두를 넓히기 위한 방법으로 전통적으로 시행되어 오던 내시경괄약근절개술 (endoscopic sphincterotomy, EST) 이외에, 확장용 풍선 도관 (dilation balloon catheter)을 이용한 내시경유두풍선확장술 (endoscopic papillary balloon dilation, $\mathrm{EPBD}$ )과 내시경유두 큰풍선확장술(endoscopic papillary large balloon dilation, EPLBD)이 도입되어 수십 년간 임상에서 시행되어 왔다. ${ }^{1,2}$ 이 두 
가지 내시경 시술방법은 담관결석의 크기에 따라 직경이 다른 풍선 도관을 사용하게 되며, 기본적인 시술의 목적과 원리, 그리고 시술과정은 매우 유사하다.

반면에 두 시술 간의 차이를 보자면, $\mathrm{EPBD}$ 는 보통 $1 \mathrm{~cm}$ 이하의 작은 담석을 치료할 목적으로 작은 직경의 풍선으로 확장술을 시행하기 때문에 유두괄약근의 기능을 어느 정도 보전할 수 있어, ${ }^{3-5} \mathrm{EST}$ 에 비하여 담석 재발과 같은 장기 합병증 발생을 줄일 수 있다는 점과 위절제술 후나 방유두게실의 존재와 같은 해부학적 변형을 가진 환자에서 효과적이라는 장점이 있다. ${ }^{6-9}$ 반면, 담도 개구부의 확장 효과가 작기 때문에 크기가 큰 결석을 제거하는 것은 용이하지 않아서, 기계적 쇄석술을 요하는 경우가 많으며, 급성 췌장염의 발생률이 EST에 비하여 더 높다. ${ }^{10,11}$

$\mathrm{EPLBD}$ 의 경우 그 정의상 직경 $12 \mathrm{~mm}$ 이상의 확장용 풍선 도관을 이용하여 유두부 및 하부 담관을 확장하는 내시경 시술이기 때문에, 직경이 $10 \mathrm{~mm}$ 이상 되는 담관결석을 치료할 목적으로 시행된다. 사용되는 확장용 풍선의 직경이 크기 때문에 유두부 확장효과가 커서, EST에 비하여 기계적 쇄석술의 사용빈도를 줄여주고, 시술시간과 X-ray 투시촬영(fluoroscopy) 시간을 단축시키며, 낮은 합병증 발생률을 보여주었다. ${ }^{12-15}$ 그러나 EST 선행 여부와 관계 없이 EPLBD는 작은 직경의 확장용 풍선을 사용하는 $\mathrm{EPBD}$ 와 달리 시술 시 유두괄약근이 파열되어 괄약근 기능의 영구적 소실이 발생하기 때문에 $\mathrm{EPBD}$ 보다 장기간 담석 재발률이 높다. ${ }^{16-19}$

본고에서 저자는 총담관결석증의 내시경 치료방법의 하나인 $\mathrm{EPBD}$ 및 $\mathrm{EPLBD}$ 의 시술 전 준비과정과 시술 대상의 선정 그리고 시술 중 기본 술기를 기술하고 본 시술의 임상적인

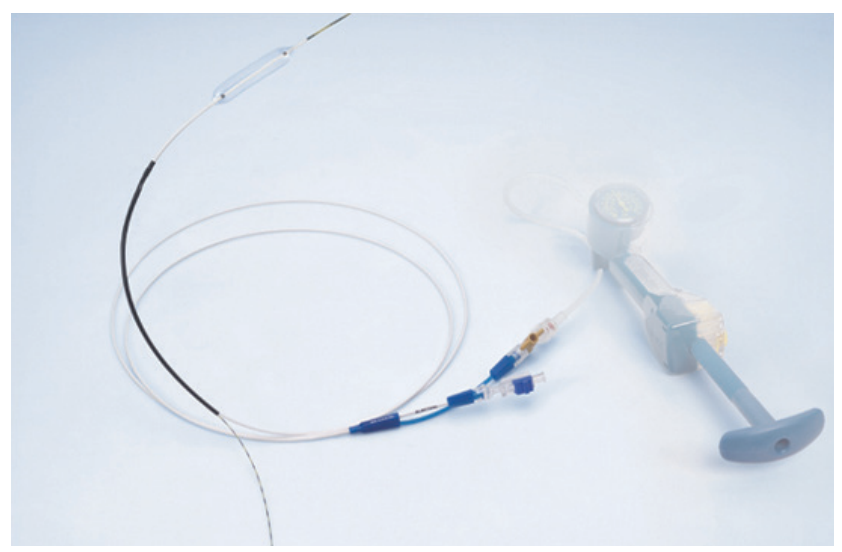

Fig. 1. Fixed, small diameter of dilation balloon catheter used for an endoscopic papillary balloon dilation. Courtesy of Boston Scientific Corp., (Marlborough, MA, USA).
이득과 안전성 및 안전하고 효과적인 실질적인 술기 요령과 가이드라인에 관하여 논하고자 한다.

\section{본 론}

\section{1. 시술 기구 준비}

\section{1) 확장용 풍선 도관}

조영제 주입용 삽입관(cannula)과 내시경역행담췌관조영술 (endoscopic retrograde cholangiopancreatography, ERCP) 시행 시 통상적으로 많이 사용되는 0.035 inch의 직경과 최소 $230 \mathrm{~cm}$ 의 길이를 가진 유도선 그리고 유도선 유도용 확장용 풍선 도관 (wire-guided balloon catheter)을 직경별로 준비한다. 확장용 풍선 도관은 직경이 고정된 모델과 직경이 풍선확장압력에 따라 직경이 가변적인 모델로 나뉘어지는데, 고정 직경의 풍선 도관 모델은 4-10 mm의 작은 직경으로 주로 담관 협착 확장술이나 $\mathrm{EPBD}$ 시행 시 사용된다(Fig. 1). 반면에 가변 직경의 풍선 도관 모델은 직경의 종류에 따라 10-12 mm, 12-15 mm, 15-18 mm 및 18-20 mm 직경의 풍선이 있다(Fig. 2).

풍선 도관은 내부에 조영제 주입용과 유도선 삽입용, 두 개의 채널을 가진다. 조영제를 조영제 주입용 채널을 통하여

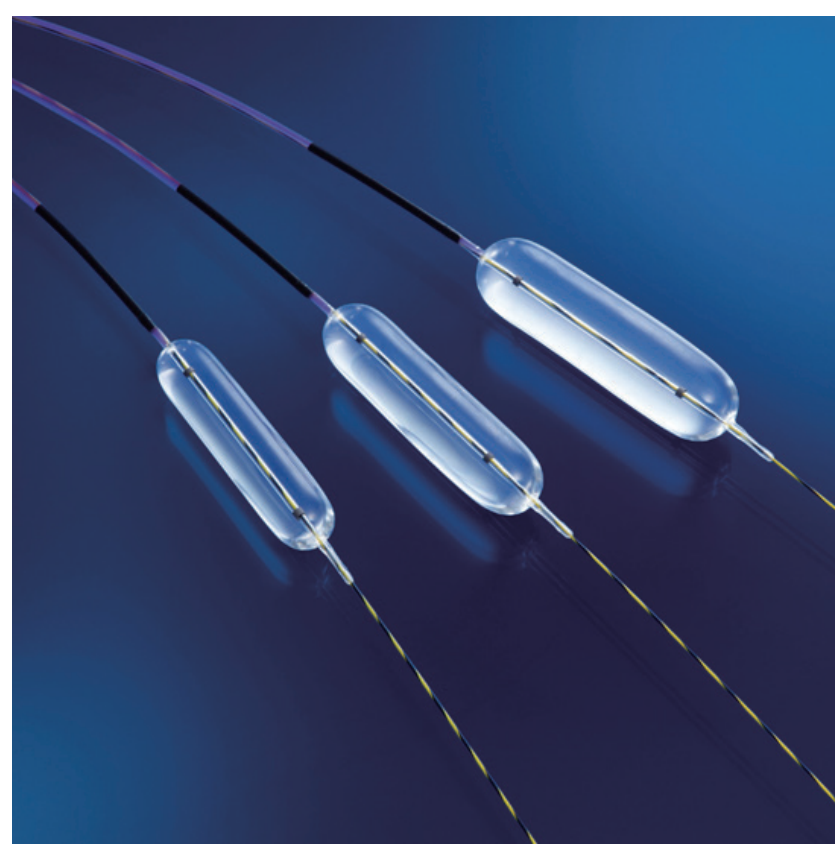

Fig. 2. Variable, large diameter of dilation balloon catheter used for an endoscopic papillary large balloon dilation. Courtesy of Boston Scientific Corp., (Marlborough, MA, USA). 
주입하여 풍선을 확장하면 소시지 모양이 되며, 풍선의 팽창은 방사상으로 균일한 압력으로 진행되는 구조를 가진다. 풍선 도관의 외경은 $7.5 \mathrm{~F}(2.5 \mathrm{~mm}$ )로 부속기구 삽입용 채널(working channel)이 최소한 $2.8 \mathrm{~mm}$ 이상이 되는 내시경을 사용해야 한다. 풍선 도관은 직경의 종류에 따라 최대 확장압력이 정해져 있으며(6-8 mm, $10 \mathrm{~atm} ; 10-12 \mathrm{~mm}, 8 \mathrm{~atm})$, 이를 초과하게 되면 풍선이 파열될 수 있다.

\section{2) 확장기}

조영제를 연결관을 통하여 풍선 도관 내로 기계적으로 주입하여 풍선을 팽창시키는 장치인 확장기(inflator)를 준비한다. 제조사마다 다양한 형태의 확장기가 나와있는데, 확장기에는 대개 선단에 압력 단위가 psi와 atm으로 표시된 압력계가 장착되어 있고, 중간부에 조영제를 최대 $20 \mathrm{~mL}$ 까지 채울 수 있는 주사기가 있으며, 후단에는 밀어서 풍선 도관 내로 조영제를 주입하는 플런저(plunger)가 달려있다(Fig. 3).

\section{2. 시술대상의 선정}

$\mathrm{EPBD}$ 와 $\mathrm{EPLBD}$ 의 시술 적응증은 주로 원발성 혹은 이차 담관결석이 된다. 그러나 $\mathrm{EPBD}$ 의 경우 $\mathrm{EPBD}$ 가 가진 한계 때문에 모든 담관결석 환자를 대상으로 $\mathrm{EPBD}$ 를 일상적으로 적용하기는 어렵다고 생각한다. EPBD와 EST의 무작위 비교 임상 연구들의 메타분석 결과를 근거로 시술 대상을 선정하여 보면, 우선 간경변증(liver cirrhosis)이나 말기 신질환 (end-stage renal disease) 등과 같이 응고병증(coagulopathy)을 동반한 담관결석 환자에서 출혈의 위험성이 큰 EST에 비하여

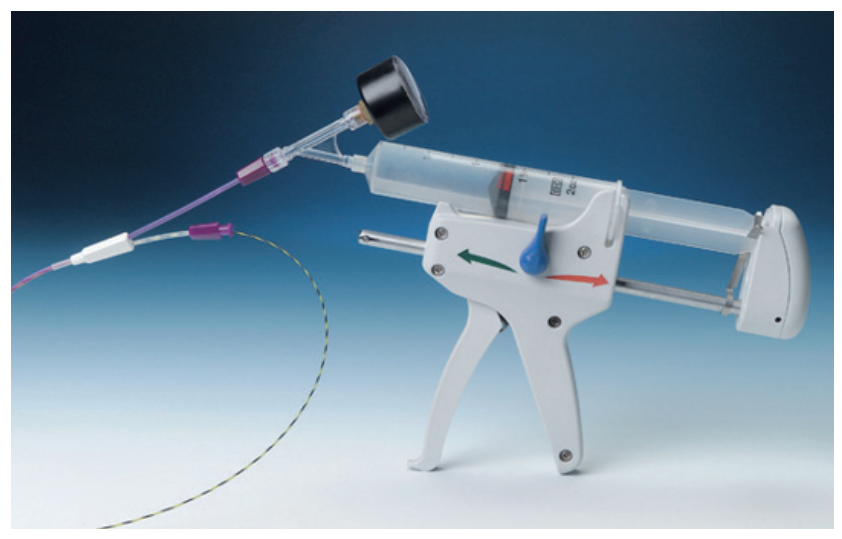

Fig. 3. An indeflator which used for mechanical injection of contrast media into the channel of dilation balloon catheter to inflate the balloon. Courtesy of Boston Scientific Corp., (Marlborough, MA, USA).
유용한 시술이 된다. ${ }^{10,11} \mathrm{EST}$ 에서보다 EPBD에서 췌장염의 발생위험이 더 큰데, 특히 60세 이하 환자에서 그 위험성이 더 크고 췌장염으로 인한 사망위험도 더 커서 주로 60 세 이상의 고령 결석 환자에서 시행할 수 있다. 그리고 Billroth II 위절제술과 같은 위우회수술을 했던 환자나 방유두게실이 있는 경우처럼 해부학적 변화를 가진 담관결석 환자에서 안전하고 효과적인 시술이 될 수 있다. ${ }^{7-9}$

또한 $\mathrm{EPBD}$ 는 담도 개구부를 확장시키는 정도가 작기 때문에 크기가 큰 결석에서 $\mathrm{EPBD}$ 를 시행하는 경우, 결석을 완전히 제거하기 위하여 기계적 쇄석술과 같은 추가적인 시술이 필요한 경우가 많아서 급성 췌장염을 일으킬 수 있는 유두부의 기계적 손상의 위험성이 있다. ${ }^{20}$ 한 임상 연구에 따르면 $10 \mathrm{~mm}$ 미만의 3 개 이하의 담관결석 환자에서 $8 \mathrm{~mm}$ 직경의 풍선 도관으로 $\mathrm{EPBD}$ 를 시행하였을 때, 추가로 $\mathrm{EST}$ 나 기계적 쇄석술이 필요 없이 거의 모든 대상자에서 성공적인 결석 제거가 가능하였으며, 시술 후 췌장염의 발생도 EST와 차이가 없었다고 하였다. 따라서 $\mathrm{EPBD}$ 가 크기가 작은 담관결석에 적절한 치료가 될 수 있다. ${ }^{21}$

$\mathrm{EPBD}$ 에 관한 대부분의 임상 연구에서 제외 기준에 하부 담관의 협착이 포함되어 있지 않지만, 특히 단단하거나 긴 분절의 양성 담관 협착이 의심되는 경우, 협착부의 섬유화로 인하여 담관의 탄성이 저하되어 있어, $\mathrm{EPBD}$ 시행 시 천공의 우려가 있기 때문에 $\mathrm{EPBD}$ 를 시행하는 데 있어 주의를 요한다. $\mathrm{EPLBD}$ 는 치료가 어려운 직경 $10 \mathrm{~mm}$ 이상의 거대 총담관결석 환자가 치료대상이 된다. ${ }^{2,13,22-26}$

\section{3. 기본 술기}

삽입관의 선택적인 담도 삽관이 성공하게 되면, 삽입관을 통하여 담관 내 조영제를 충분히 주입하여 담관조영술을 시행한다. 담관조영 검사에서 담관의 전체적인 모양을 파악하고, 이미 알고 있는 십이지장경의 원위부 말단의 외부 직경 $(13.5 \mathrm{~cm})$ 을 기준으로 담관의 최대 직경을 대략 정하고 담관 내 가장 큰 결석의 최대 직경을 파악한 뒤, 사용할 풍선의 직경을 결정한다.

삽입관의 내강을 통하여 유도선을 담관 내로 충분한 길이를 삽입하고 나서 삽입관을 제거한 후, 유도선을 따라 허탈된 상태의 확장용 풍선 도관을 진입시켜 내시경 화면을 보면서 확장용 풍선의 중간부위가 유두개구부에 위치하도록 한다. 이 때 시술 보조자는 내시경의 부속기구 삽입용 채널 밖으로 나와 
있는 풍선 도관의 근위부 말단에 있는 조영제 주입용 채널에 조영제를 채워둔 확장기의 연결관을 연결한다. 시술자가 X-ray 투시기와 내시경 화면을 계속 관찰하면서 보조자로 하여금 플런저를 서서히 전방으로 밀어서 확장기 내에 있는 조영제를 풍선 내로 주입하여 채우게 함으로써, 목표로 하는 풍선의 직경과 압력까지 풍선을 서서히 팽창시킨다. 목표로 하는 직경까지 풍선을 팽창시키면 X-ray 투시기에서 풍선 중간부에 balloon waist 혹은 절흔 징후(notch sign)가 나타나는데, 이것은 팽창되는 풍선에 의하여 밀려 확장되고 있는 오디 괄약근의 위치이다. 이 balloon waist가 사라질 때까지 풍선을 팽창시키고, 팽창된 풍선의 압력을 일정시간 유지시킨다(Fig. 4).

이후 다시 플런저를 후방으로 당겨서 팽창된 풍선 내의 조영제를 빼내고 풍선을 수축시켜 허탈시킨 뒤, 내시경 밖으로 풍선 도관을 제거한다. 넓혀진 유두 개구부를 통하여 바스켓이나 결석 회수용 풍선 도관을 이용하여 담관결석을 십이지장 내로 빼내어 제거하게 된다. 이러한 과정에서 시술 후 급성 췌장염 발생의 위험을 줄이기 위해서는 유두부에 기계적 손상을 최소화하는 방향으로 시술을 시행하도록 하는데, 이러한 목적을 달성하기 위하여 EPBD 및 EPLBD 시술과 관련된 몇 가지 요인들에 대한 고려가 필요하다.

\section{1) 풍선 직경}

$\mathrm{EPBD}$ 와 $\mathrm{EPLBD}$ 에서 사용할 풍선의 직경을 결정하는 방법은
십이지장경의 원위부 말단의 외경을 기준으로 담관의 최대 직경과 담관 내 가장 큰 결석의 최대 직경을 파악하여 풍선의 직경을 결정하는데, 이 때 췌장염 발생을 피할 수 있는 최선의 풍선 직경은 총수담관의 직경보다는 작으면서 담관 내 최대 결석보다 크거나 같은 것을 선택하는 것이 췌관 개구부의 손상을 최소화할 수 있다고 생각한다. ${ }^{20}$

\section{2) 풍선확장압력}

$\mathrm{EPBD}$ 를 시행할 때의 풍선확장압력도 이론적으로 유두부 손상과 관련이 있다고 할 수 있는데, 아직까지 이와 관련한 연구가 미미한 상태이다. Tsujino 등 ${ }^{27}$ 은 낮은 풍선확장압력과 짧은 풍선확장시간이 유두부에 손상을 덜 줘서 합병증을 줄일 수 있음을 보여주었고, Nakagawa 와 Ohara ${ }^{28}$ 는 EPBD 후 췌장염 발생의 위험요인에 관한 연구에서 절흔 징후 소실에 필요한 풍선확장압력이 $5 \mathrm{~atm}$ 이상이었던 2명의 환자에서 시술 후 췌장염 발생을 보고하였다. 만약 절흔 징후 소실을 위하여 높은 풍선확장압력이 필요한 경우에 췌장염 발생과 관련이 있다는 것이 사실이라면, $\mathrm{EPBD}$ 중 절흔 징후가 $5 \mathrm{~atm}$ 이상의 높은 풍선확장압력에서도 소실되지 않는 경우, $\mathrm{EPBD}$ 를 중단하고 EST로 전환하여야 한다. ${ }^{20}$

$\mathrm{EPLBD}$ 의 경우, 풍선확장압력과 관련한 직접적인 임상 데이터는 없으나, 관련 임상 데이터의 문헌고찰 분석에 기반한 안전한 EPLBD 시술의 가이드라인에 따르면, 해당 직경에서
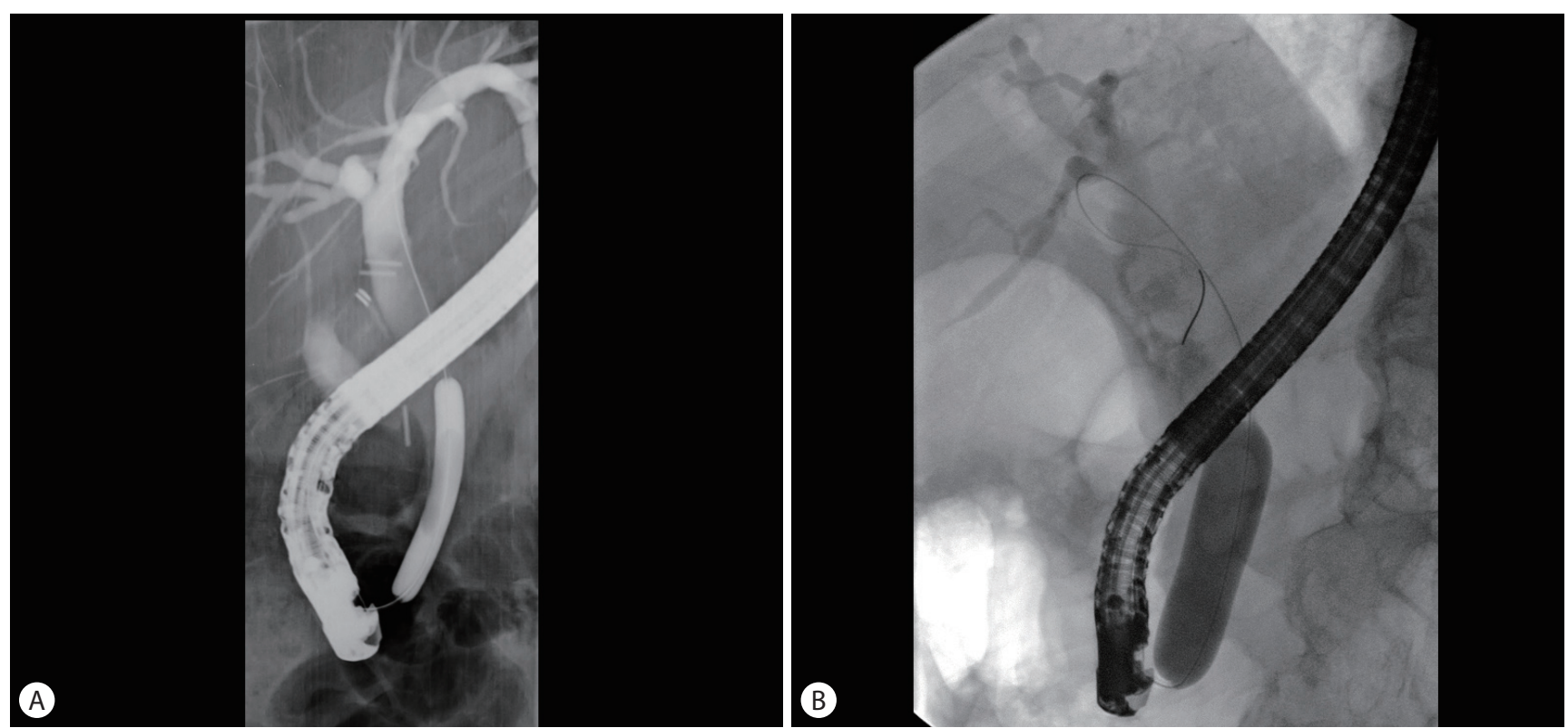

Fig. 4. Fluoroscopic findings of (A) endoscopic papillary balloon dilation and (B) endoscopic papillary large balloon dilation. 
권고하는 최대 압력의 $75 \%$ 에 도달 시에도 풍선 도관의 절흔징후 소실이 없는 경우, 그 이상 압력 상승은 담관 천공의 위험성 때문에 지양하도록 권고하고 있으며, ${ }^{29}$ 저자의 개인적인 경험에 의하면 3-5 atm 이하의 낮은 확장압력으로도 충분한 유두부 확장효과를 얻으면서 췌장염과 천공같은 심각한 합병증을 예방할 수 있다고 생각한다.

\section{3) 풍선확장시간}

목표 직경까지 팽창된 풍선으로 하부담관과 유두부의 확장을 유지하는 시간인 풍선확장시간은 $\mathrm{EPBD}$ 관련 임상 연구에서 15-120초 사이였으며, 대부분의 연구자들은 주로 60 초를 사용하였다. 그러나 담석 재발과 같은 장기 합병증을 줄이기 위하여 유두괄약근 손상을 최소화하는 방향의 시술을 고려한다면, 이론적으로 가능한 풍선확장시간을 단축하는 것이 타당할 것이다. Tsujino 등 ${ }^{27}$ 은 EPBD 임상 연구에서 대부분의 환자가 풍선확장시간 15초 이내에 balloon waist가 소실되므로, 15 초면 유두부의 풍선확장효과가 충분하다고 보고, 이것이 유두부 손상을 최소화하고 최소한의 유두괄약근 확장효과를 낼 수 있는 시간으로 판단하여, 120 초군과 비교하였는데, 15 초군에서 췌장염의 발생률이 낮은 경향을 보였으며 $(4.0 \% \mathrm{vs.}$ $7.4 \%, p=0.0626$ ), 중증 췌장염의 발생은 유의하게 낮았다고 보고하였다. 또한 $\mathrm{Bang}$ 등 $^{30}$ 의 $\mathrm{EPBD}$ 에서 풍선확장시간에 관한 비교 연구에서도 췌장염 발생률에 있어 비슷한 결과를 보고하였다 $(20$ 초군 $5.7 \%$ vs. 60 초군 $11.4 \%, p=0.393)$. 또한 단단하거나 긴 분절의 담관 협착이 의심되는 경우, $\mathrm{EPBD}$ 가 꼭 필요한 시술인지 신중히 고려해야 하며, $\mathrm{EPBD}$ 도중에 담관 협착이 의심되고 balloon waist가 나타난 뒤 20여 초 이상 경과 후에도 소실되지 않고 지속 시에는 풍선확장 시술의 중단을 고려해야한다.

EPLBD의 경우 관련 임상 연구에서 풍선확장시간이 대부분 1 분이었으며, 풍선확장시간에 따른 임상 성적을 비교하였던 EPLBD 연구는 아직 없다. EPLBD에 관한 개인적인 경험에 의하면 특히 EST 선행 없이 EPLBD를 시행하는 경우, 일부 환자에서 유두부 확장 효과가 떨어지거나 일시적인 경향성이 있어서, 낮은 확장압력과 느린 확장속도를 유지하면서 풍선확장시간을 최소 2 분 이상으로 연장 시, 시술 합병증의 위험 없이 확장 효과를 높이거나 유지시켜주는 경향이 있다고 생각한다.

\section{4) 풍선확장속도}

실제 풍선확장속도를 정확하게 측정하기 어렵기 때문에 대부분의 $\mathrm{EPBD}$ 및 $\mathrm{EPLBD}$ 의 임상 연구에서 이에 관한 정확한 기술이 안되어 있고, 관련 연구도 미미한 실정이나, 15 초 당 $0.5 \mathrm{~atm}$ 의 느린 풍선확장속도를 사용한 한 $\mathrm{EPBD}$ 연구에서 $4.0 \%$ 의 낮은 췌장염 발생률을 보였으며, 서서히 풍선확장을 시행하였다고 기술된 연구들에서 췌장염 발생률이 낮은 경향을 보였다. ${ }^{27}$

$\mathrm{EPBD}$ 에 사용되는 풍선 도관들은 일반적으로 polyethylene terephthalate나 nylon으로 제작되므로, 낮은 압력에서도 신속히 팽창되고 $0.5 \mathrm{~atm}$ 의 낮은 확장압력에서도 풍선의 직경이 완전히 팽창된 풍선 직경의 $90 \%$ 이상 도달할 수 있다. 따라서 풍선을 서서히 팽창시키는 $\mathrm{EPBD}$ 는 오디 괄약근에 손상 위험을 줄이는 데 매우 중요할 수 있으며, 특히 풍선 팽창 시작 후 첫 0-2 atm 중에 풍선 팽창을 서서히 하는 것이 중요하다. 이러한 풍선확장속도는 안전한 $\mathrm{EPBD}$ 의 가장 중요한 요인일 것으로 제시되었으며, 저자도 이 의견에 전적으로 동의한다. ${ }^{20} \mathrm{EPLBD}$ 의 경우에도 관련 임상 연구 데이터는 없지만, 개인적으로 $\mathrm{EPBD}$ 에서와 마찬가지로 풍선확장속도를 낮게 유지하는 것이 합병증 발생률을 낮게 유지하는 방법 중 하나라고 생각한다.

\section{5) 풍선확장횟수}

안전하고 효과적인 $\mathrm{EPBD}$ 및 $\mathrm{EPLBD}$ 를 위하여 풍선확장을 반복해야 하는지에 대하여 아직 알려진 바는 없다. 대부분 $\mathrm{EPBD}$ 와 $\mathrm{EPLBD}$ 의 임상 연구에서 관습적으로 1 회의 풍선확장을 시행하였다. 저자의 경우, $\mathrm{EPBD}$ 및 $\mathrm{EPLBD}$ 시술 시행 시, 1 회의 풍선유두부확장 시술 후 확장 효과가 부족하다고 판단되는 경우, 동일 $\mathrm{ERCP}$ 세션에서 추가로 여러 번 풍선확장술을 반복하거나, 다른 ERCP 세션에서 반복적인 풍선확장술을 시행하기도 하는데, 이러한 경우 시술 합병증 발생의 증가 없이 유두부 확장 효과가 증가하는 경향을 경험하였다.

\section{6) 시술자가 숙지해야 할 안전하고 효과적인 EPLBD의 가이드라인}

2012년 대규모 임상 연구의 다변량 분석에 근거하여 다음과 같이 $\mathrm{EPLBD}$ 의 가이드라인이 소개되었다. ${ }^{29}$

1. 하부담관의 협착을 동반하지 않은 확장된 담관을 가진 환자가 $\mathrm{EPLBD}$ 의 적응증이 된다.

2. EPLBD 시행 전에 시행하는 EST를 시행함에 있어 천공과 출혈의 합병증을 예방하기 위하여 대절개를 피한다. 
3. 풍선유두부 확장술 시행 시 풍선의 팽창을 낮은 압력으로 서서히 진행하여야 하며, 이를 통하여 풍선확장 도중 절흔 징후의 지속을 확인하여 시술 전 확인이 되지 않았거나 숨어있던 하부 담관 협착을 찾는다.

4. 풍선확장 시술 중 저항이나 지속적인 절흔 징후 발생 시, 풍선 도관의 과팽창을 피한다.

1) 하부 담관의 협착을 시사하는 풍선확장 중 유두부의 심한 저항 발생 시, 풍선확장압력을 올리지 말고 풍선확장술을 중단한다.

2) 풍선유두부확장술 시행 시, 권고하는 최대 풍선확장 압력의 $75 \%$ 까지 도달 시에도 풍선 도관 중간에 나타나는 절흔 징후가 소실되지 않고 지속 시, 풍선확장압력을 올리지 말고 풍선확장시술을 중단한다.

5. EPLBD 시술 전 하부담관의 최대 직경을 초과하는 확장용 풍선 도관을 선택하지 않으며, 담관의 최대 직경을 초과한 풍선확장술을 시행하지 않는다.

6. 풍선유두부확장 도중 필요한 경우, 기계적 쇄석술이나 스텐트 삽입술과 같은 대안이 되는 결석제거방법으로의 전환을 주저하지 않는다.

\section{4. 임상적 미충족 수요}

총담관결석 치료가 주 목적인 $\mathrm{EPBD}$ 와 $\mathrm{EPLBD}$ 는 본 시술을 통하여 합병증 없이 담관 입구의 확장을 통하여, 결석을 제거할 때 담관 입구에서 저항 없이 결석을 쉽게 십이지장으로 회수할 수 있어야 한다. 그러나 기본적으로 담관과 유두부의 생체 조직은 탄성을 가지고 있어서 풍선에 의한 유두부 확장 직후, 풍선을 제거하면 조직의 탄력 반동(elastic recoil)에 의하여 담관 입구의 확장이 일시적이거나 효과적이지 않은 경우가 발생 한다. 따라서 효과적이고 안전한 $\mathrm{EPBD}$ 가 되기 위하여 높은 수준의 근거를 제공할 수 있는 임상 연구들을 통하여 적절한 시술 프로토콜의 개발이 요구된다.

\section{결 론}

$\mathrm{EPBD}$ 및 $\mathrm{EPLBD}$ 는 특히 $\mathrm{ERCP}$ 를 시작하는 초심자들에게 있어 EST에 비하여 기술적인 측면에서 시행이 용이하므로, 시술에 앞서 시술자가 $\mathrm{EPBD}$ 와 $\mathrm{EPLBD}$ 의 장단점을 파악하고 적절한 시술 대상을 선정하며 안전하고 효과적인 술기 요령을 숙지한다면, 임상에서 많은 췌담도 내시경의들에게 있어
담관결석 제거를 위한 내시경 치료의 좋은 방법이 될 수 있다.

\section{요 약}

내시경유두풍선확장술(EPBD)과 내시경유두큰풍선확장술 (EPLBD)은 총담관결석의 치료를 위하여 지난 수십 년간 전 세계적으로 시행되어왔다. 직경이 작은 확장용 풍선 도관을 이용한 $\mathrm{EPBD}$ 는 내시경괄약근절개술(EST)에 비하여 유두괄약근의 기능을 보존하며 담관결석의 재발률을 감소시킬 수 있다. 또한 이들 시술은 출혈 발생 위험성이 낮아서 응고병증이나 간경변, 말기신질환 및 Billroth 위절제술과 같은 외과적으로 변화된 해부구조를 가지거나 방유두게실이 있는 환자에 적합하다. 그러나 시술 후 췌장염 발생의 위험은 더 크다. $12 \mathrm{~mm}$ 이상 직경의 큰 풍선 도관을 이용한 $\mathrm{EPLBD}$ 는 총담관결석이 $10 \mathrm{~mm}$ 이상으로 큰 경우에 적합하다. $\mathrm{EPLBD}$ 의 장점으로 EST 선행 여부와 관계 없이 기계적 쇄석술의 필요성을 줄여 시술시간을 단축하고, 방사선 노출시간을 줄일 수 있다는 것이다. 그리고 완전 결석제거에 필요한 ERCP 횟수도 줄여서 보다 비용-효과적이다. EPLBD에서의 시술 후 췌장염의 발생률은 $\mathrm{EST}$ 에 비하여 낮다. $\mathrm{EPBD}$ 와 $\mathrm{EPLBD}$ 는 안전한 시술 가이드라인을 준수하여 시행한다면, 총담관결석증 치료에 있어서 안전하고 효과적이며 EST의 대안이 될 수 있을 것이다.

국문 색인: 총담관결석증, 내시경유두풍선확장술, 내시경유두 큰풍선확장술, 내시경괄약근절개술

\section{Conflicts of Interest}

The author has no conflicts to disclose.

\section{REFERENCES}

1. Staritz M, Ewe K, Meyer zum Büschenfelde KH. Endoscopic papillary dilation (EPD) for the treatment of common bile duct stones and papillary stenosis. Endoscopy 1983;15 Suppl 1:197-198.

2. Ersoz G, Tekesin 0, Ozutemiz A0, Gunsar F. Biliary sphincterotomy plus dilation with a large balloon for bile duct stones that are difficult to extract. Gastrointest Endosc 2003;57:156-159.

3. Minami A, Nakatsu T, Uchida $N$, et al. Papillary dilation vs sphincterotomy in endoscopic removal of bile duct stones. A randomized trial with manometric function. Dig Dis Sci 1995;40:2550-2554.

4. Sato H, Kodama T, Takaaki J, et al. Endoscopic papillary balloon 
dilatation may preserve sphincter of Oddi function after common bile duct stone management: evaluation from the viewpoint of endoscopic manometry. Gut 1997;41:541-544.

5. Yasuda I, Tomita E, Enya M, Kato T, Moriwaki H. Can endoscopic papillary balloon dilation really preserve sphincter of Oddi function? Gut 2001;49:686-691.

6. Yasuda I, Fujita N, Maguchi H, et al. Long-term outcomes after endoscopic sphincterotomy versus endoscopic papillary balloon dilation for bile duct stones. Gastrointest Endosc 2010;72:1185-1191.

7. Ito $Y$, Tsujino T, Togawa 0 , et al. Endoscopic papillary balloon dilation for the management of bile duct stones in patients 85 years of age and older. Gastrointest Endosc 2008;68:477-482.

8. Toda N, Saito K, Wada R, et al. Endoscopic sphincterotomy and papillary balloon dilation for bile duct stones. Hepatogastroenterology 2005;52:700704.

9. Bergman JJ, van Berkel AM, Bruno MJ, et al. A randomized trial of endoscopic balloon dilation and endoscopic sphincterotomy for removal of bile duct stones in patients with a prior Billroth II gastrectomy. Gastrointest Endosc 2001;53:19-26.

10. Baron TH, Harewood GC. Endoscopic balloon dilation of the biliary sphincter compared to endoscopic biliary sphincterotomy for removal of common bile duct stones during ERCP: a metaanalysis of randomized, controlled trials. Am J Gastroenterol 2004;99:1455-1460.

11. Weinberg BM, Shindy W, Lo S. Endoscopic balloon sphincter dilation (sphincteroplasty) versus sphincterotomy for common bile duct stones. Cochrane Database Syst Rev 2006;4:CD004890.

12. Heo JH, Kang DH, Jung HJ, et al. Endoscopic sphincterotomy plus large-balloon dilation versus endoscopic sphinc $\neg$ terotomy for removal of bile-duct stones. Gastrointest Endosc 2007;66:720-726.

13. Itoi T, Itokawa F, Sofuni A, et al. Endoscopic sphincterotomy combined with large balloon dilation can reduce the procedure time and fluoroscopy time for removal of large bile duct stones. Am J Gastroenterol 2009;104:560-565.

14. Yang XM, Hu B. Endoscopic sphincterotomy plus large-balloon dilation vs endoscopic sphincterotomy for choledocholithiasis: a meta-analysis. World J Gastroenterol 2013;19:9453-9460.

15. Park JS, Jeong S, Lee DK, et al. Comparison of endoscopic papillary large balloon dilation with or without endoscopic sphincterotomy for the treatment of large bile duct stones. Endoscopy 2019;51:125-132.

16. Cheon YK, Lee TY, Kim SN, Shim CS. Impact of endoscopic papillary large-balloon dilation on sphincter of Oddi function: a prospective randomized study. Gastrointest Endosc 2017;85:782-790.

17. Chan $\mathrm{HH}$, Lai $\mathrm{KH}$, Lin CK, et al. Endoscopic papillary large balloon dilation alone without sphincterotomy for the treatment of large common bile duct stones. BMC Gastroenterol 2011;11:69.

18. Kogure $H$, Tsujino $T$, Isayama $H$, et al. Short- and long-term outcomes of endoscopic papillary large balloon dilation with or without sphincterotomy for removal of large bile duct stones. Scand I Gastroenterol 2014;49:121-128.

19. Park JS, Jeong S, Bang BW, Kang AR, Lee DH. Endoscopic papillary large balloon dilatation without sphincterotomy for the treatment of large common bile duct stone: long-term outcomes at a single center. Dig Dis Sci 2016;61:3045-3053.

20. Aiura K, Kitagawa Y. Current status of endoscopic papillary balloon dilation for the treatment of bile duct stones. J Hepatobiliary Pancreat Sci 2011;18:339-345.

21. Bergman JJ, Tytgat GN, Huibregtse K. Endoscopic dilatation of the biliary sphincter for removal of bile duct stones: an overview of current indications and limitations. Scand J Gastroenterol Suppl 1998;225:59-65.

22. Maydeo A, Bhandari S. Balloon sphincteroplasty for removing difficult bile duct stones. Endoscopy 2007;39:958-961.

23. Minami A, Hirose $S$, Nomoto $T$, Hayakawa $S$. Small sphincterotomy combined with papillary dilation with large balloon permits retrieval of large stones without mechanical lithotripsy. World I Gastroenterol 2007;13:2179-2182.

24. Attasaranya S, Cheon YK, Vittal H, et al. Large-diameter biliary orifice balloon dilation to aid in endoscopic bile duct stone removal: a multicenter series. Gastrointest Endosc 2008;67:1046-1052.

25. Bang S, Kim MH, Park JY, Park SW, Song SY, Chung JB. Endoscopic papillary balloon dilation with large balloon after limited sphincterotomy for retrieval of choledocholithiasis. Yonsei Med J 2006;47:805810.

26. Kim TH, Oh HJ, Lee JY, Sohn YW. Can a small endoscopic sphincterotomy plus a large-balloon dilation reduce the use of mechanical lithotripsy in patients with large bile duct stones? Surg Endosc 2011;25:3330-3337.

27. Tsujino $T$, Kawabe $T$, Isayama $H$, et al. Efficacy and safety of low-pressured and short-time dilation in endoscopic papillary balloon dilation for bile duct stone removal. J Gastroenterol Hepatol 2008;23:867-871.

28. Nakagawa H, Ohara K. Safeguards against acute pancreatitis associated with endoscopic papillary balloon dilatation. J Hepatobiliary Pancreat Surg 2006;13:75-79.

29. Lee DK, Han JW. Endoscopic papillary large balloon dilation: guidelines for pursuing zero mortality. Clin Endosc 2012;45:299-304.

30. Bang BW, Jeong $\mathrm{S}$, Lee $\mathrm{DH}$, et al. The ballooning time in endoscopic papillary balloon dilation for the treatment of bile duct stones. Korean J Intern Med 2010;25:239-245. 